\title{
AVAILABILITY OF ORGANIC CARBON IN SOLUBLE AND PARTICLE-SIZE FRACTIONS FROM A SOIL PROFILE
}

\author{
P. N. Nelson*, M-C. Dictor and G. Soulas \\ Laboratoire de microbiologie des sols, INRA, 17 rue Sully, B.P. 1540, 21034 Dijon Cedex, France
}

\author{
(Accepted 7 April 1994)
}

\begin{abstract}
Summary - In an agricultural soil profile, the availability of soil organic $\mathrm{C}$ for microbial activity decreased from 0 to $100 \mathrm{~cm}$ depth in winter, spring and summer. Availability was defined as the ratio of respiration rate to total organic $\mathrm{C}$, or the ratio of microbial biomass $\mathrm{C}$ to total organic $\mathrm{C}$. The amount and availability of organic $C$ in various soil fractions was measured. Fractions consisted of aqueous extracts from throughout the profile, and particle-size and density fractions from the 0-20 and $80-100 \mathrm{~cm}$ layers. The fractions were incubated with soil inoculum for 24 or 28 days. Availability of organic $\mathrm{C}$ in soluble fractions was measured by the decrease in dissolved organic $\mathrm{C}$. Availability of organic $\mathrm{C}$ in insoluble fractions was measured by the increase in inorganic $C$. Availability of organic $\mathbf{C}$ in all fractions was similar at each depth, except for the weakly-adsorbed and clay fractions, in which organic $\mathrm{C}$ was less available at depth. Availability was least in the silt fractions. Approximately half of the organic $\mathrm{C}$ mineralized during incubations originated from the clay fraction in both the $0-10$ and $80-100 \mathrm{~cm}$ layers. Of the remainder, at the surface a higher proportion was in the silt and light ( $>50 \mu \mathrm{m}, d<2 \mathrm{~g} \mathrm{~cm}^{-3}$ ) fractions, due to a larger proportion of total organic $\mathrm{C}$ in those fractions. At depth, a higher proportion was in the extracted fractions. The decrease in the availability of total organic $C$ with depth appeared mainly to be due to a decrease in the accessibility of organic $\mathrm{C}$ to microorganisms, and a decrease in the availability of clay fraction organic $\mathrm{C}$.
\end{abstract}

\section{INTRODUCTION}

In a soil profile being studied for pesticide degradation, the rate of mineralization of added organic compounds was found to decrease markedly with depth in the top $1 \mathrm{~m}$ of the profile, in parallel with microbial biomass and total organic C (Dictor et al., 1992). Microbial activity at depth is limited by the availability of organic C (Ghiorse and Wilson, 1988), and not only does the quantity of organic $\mathrm{C}$ decrease with depth, but ${ }^{14} \mathrm{C}$ dating has shown that organic $\mathrm{C}$ in deeper horizons also has longer residence times, indicating lower availability (Oades, 1989). Our aim was to investigate the change in availability of organic $C$ with depth in order to aid understanding of microbial activity in the profile under study.

Readily-available organic $\mathbf{C}$ consists of that which is readily mineralized or assimilated into biomass. Thus, if the biomass is at equilibrium, basal respiration is a measure of substrate availability (Davidson et al., 1987; Shan-Min et al., 1987). Available organic C, as measured by respiration, is significantly correlated with water-extracted organic $\mathrm{C}$ when soils with a wide range of properties are included (Burford and Bremner, 1975; Davidson et al., 1987). Davidson et al. (1987) stated that water-extracted organic $C$ was "almost certainly available", and was the immediate

*Author for correspondence, presently at: Department of Soil Science, Waite Campus, University of Adelaide, Glen Osmond, SA 5064, Australia. substrate for microorganisms. However, Beauchamp et al. (1989) suggested that a significant proportion of water-extracted $\mathrm{C}$ was not available to denitrifying microorganisms. Using incubation studies, Zsolnay and Steindl (1991) found that $85 \%$ of water-extracted organic $C$ was biodegradable. Boissier and Fontvieille (1993) used a shorter incubation period and found that biodegradability of dissolved organic C (DOC) varied from 3.8 to $39.9 \%$ in leachates from two soils.

In order to avoid the problems involved with extractions, physical fractionation of whole soils by particle size and density has increasingly been used to assess organic matter dynamics by comparing the amount and stability of organic $\mathrm{C}$ in the various fractions (Christensen, 1992). The availability of organic $\mathrm{C}$ in particle size fractions has been measured using incubation studies (Christensen, 1992; Nicolardot et al., 1992).

We have measured the quantity of organic $\mathrm{C}$ in soluble and insoluble fractions at different depths, and the availability of organic $\mathrm{C}$ in these fractions to microorganisms.

\section{MATERIALS AND METHODS}

\section{Experimental site and soil sampling}

The soil profile studied is a Gleyic Luvisol (FAO classification) in the valley of the Sâone in France. The main soil properties are shown in Table 1. The site was cropped to soya, with annual mouldboard ploughing 
Table 1. Soil properties (spring sampling)

\begin{tabular}{|c|c|c|c|c|c|c|c|}
\hline \multirow[b]{2}{*}{ Depth $(\mathrm{cm})$} & \multicolumn{3}{|c|}{ Particle size distribution $(\%)$} & \multirow[b]{2}{*}{$\mathrm{pH}(1 \mathrm{M} \mathrm{KCl})$} & \multirow[b]{2}{*}{ WHC $(\%)^{*}$} & \multirow[b]{2}{*}{ Total organic $\mathrm{C}\left(\mathrm{g} \mathrm{kg}^{-1}\right)^{7}$} & \multirow[b]{2}{*}{ C-to-N ratiot } \\
\hline & Clay & Silt & Sand & & & & \\
\hline $0-20$ & 21.9 & 57.3 & 20.8 & 7.2 & 20.4 & $8.10 \pm 0.21$ & $8.52 \pm 0.43$ \\
\hline $20-40$ & 24.3 & 56.0 & 19.7 & 7.3 & 20.0 & $6.57 \pm 0.30$ & $8.17 \pm 0.61$ \\
\hline $40-60$ & 24.9 & 55.7 & 19.4 & 7.2 & 20.9 & $2.63+0.11$ & $7.29 \pm 1.06$ \\
\hline $60-80$ & 36.0 & 46.2 & 17.8 & 6.9 & 25.0 & $1.97 \pm 0.05$ & $6.15 \pm 0.83$ \\
\hline $80-100$ & 50.4 & 33.1 & 16.5 & 6.6 & 35.1 & $1.80 \pm 0.09$ & $5.41 \pm 0.76$ \\
\hline
\end{tabular}

*Water holding capacity (\% gravimetric water content). ${ }^{+}$Mean of winter, spring and summer samplings \pm SD.

to approximately $20 \mathrm{~cm}$ until 1991 , when a ryegrass sward was established. Samples were taken in winter (19 December 1991), spring (23 April 1992) and summer (16 July 1992) using a coring system which prevented cross-contamination of the layers sampled. On each occasion, 6 cores were taken from the same $15 \times 15 \mathrm{~m}$ plot, combined into 5 samples $(0-20$, $20-40,40-60,60-80$ and $80-100 \mathrm{~cm}$ depth) and stored at field water content in air-tight plastic bags at $4^{\circ} \mathrm{C}$. Analyses were carried out within 1 week of collection. All results are given on an oven-dry soil weight basis.

\section{Measurement of organic and inorganic $C$}

Total organic $C$ in all solid samples except for the light fractions was measured by dichromate oxidation (Anne, 1945). Total $\mathrm{N}$ content was measured by Kjeldahl digestion. Total organic $\mathrm{C}$ content of light fractions was measured by combustion (Carlo Erba elemental analyser). Dissolved inorganic $\mathrm{C}$ was measured by IR detection of $\mathrm{CO}_{2}$ generated by acidification and sparging. DOC was measured by IR detection of $\mathrm{CO}$, after UV-catalysed persulphate oxidation following removal of dissolved inorganic $\mathrm{C}$. Both dissolved inorganic $\mathrm{C}$ and DOC were measured using a Dohrman DC 80 apparatus (Wu et al., 1990). Basal respiration was measured by incubating unsieved field-moist soil samples ( $20 \mathrm{~g}, 6$ replicates) in the dark at $20^{\circ} \mathrm{C}$ in sealed $125 \mathrm{ml}$ plasma vials. Headspace gas samples were taken at 3 and 10 days and analysed for $\mathrm{CO}_{2}$ by gas chromatography. The 3-day conditioning allowed the perturbing effects of sampling and temperature change to subside. Soil from the first sampling (winter) was kept at $28^{\circ} \mathrm{C}$. This temperature was considered inappropriately high, and subsequent samples were kept at $20^{\circ} \mathrm{C}$. However, to provide an approximate comparison between the three sampling dates, the results of the winter sampling were retained and converted to estimated respiration at $20^{\circ} \mathrm{C}$ using a $Q_{10}$ of 2 . Soil biomass $\mathrm{C}$ was measured by fumigation-extraction (Wu et al., 1990), using a fumigation time of $16 \mathrm{~h}$ (Chaussod et al., 1988) and an extractant concentration of $25 \mathrm{mM} \mathrm{K}_{2} \mathrm{SO}_{4}$. A $K_{\mathrm{c}}$ factor of 0.45 was used (Wu et al., 1990), and was assumed to be the same throughout the profile.

\section{Soil extraction}

Extracts were prepared by shaking unsieved, fieldmoist soil (spring and summer) with water or phosphate buffer $\left(3.33 \mathrm{~mm} \mathrm{KH}_{2} \mathrm{PO}_{4}\right.$ and $6.67 \mathrm{~mm}$ $\mathrm{Na}_{2} \mathrm{HPO}_{4}, \mathrm{pH} 7$ ). A $1: 2$ soil-to-solution ratio was used, with 4 replicates from each layer. The suspensions were shaken for $1 \mathrm{~h}$ at $20^{\circ} \mathrm{C}$ on an orbital shaker. They were then centrifuged $(6500 \mathrm{~g}, 30 \mathrm{~min})$ and sterilized by filtration through Whatman Polycap 36 AS nylon filters $(0.2 \mu \mathrm{m}$ pore size $)$. The filters were rinsed with 21 . of water and $200 \mathrm{ml}$ of sample before use.

\section{Availability of extracted organic $C$}

Availability of extracted organic $\mathrm{C}$ was measured using a method adapted from that of Servais et al. (1989). It was based on the decrease in DOC during exposure to a soil inoculum. Thus when referring to extracts, "available organic C" indicates both that assimilated by the microorganisms and that mineralized to $\mathrm{CO}_{2}$ during the incubation. Incubations were carried out in $120 \mathrm{ml}$ penicillin vials with Teflon-lined silicone rubber septa. Sterile extract $(25 \mathrm{ml})$ and $0.5 \mathrm{ml}$ of inoculum $(100 \mathrm{mg}$ of field-moist $0-20 \mathrm{~cm}$ soil suspended in 11 . of $2.2 \mathrm{mM} \mathrm{Na}_{4} \mathrm{P}_{2} \mathrm{O}_{7}$ ) were added to the vials. They were then kept in the dark at $20^{\circ} \mathrm{C}$ on an orbital shaker. Concentrated buffer $(0.5 \mathrm{ml})$ was added to vials containing water extract in order to bring them to the same buffer concentration as those containing buffer extract. Inoculum contained $0.68-0.99 \mathrm{mg} \mathrm{l}^{-1}$ total organic C. After 0 and 28 days of incubation, DOC concentration was measured following centrifugation of the vials $(5200 \mathrm{~g}$ for $15 \mathrm{~min}$ in a swing-out rotor). All incubations were carried out in quadruplicate and included incubation of a blank extract. Vials contained more than 14 times the amount of $\mathrm{O}_{2}$ needed to mineralize all of the organic $\mathrm{C}$ present. Plate counts of colony forming units (cfu) in inoculum and incubation solutions were made on nutrient agar diluted to $1 / 40$ of normal strength (resulting in $71 \mathrm{mg} \mathrm{DOC} 1^{-1}$ ). Plate counts of inoculum were between $1.9 \times 10^{3}$ and $3.3 \times 10^{3} \mathrm{cfu}$ $\mathrm{ml}^{-1}$. During extract incubations, cfu counts reached approximately $10^{6} \mathrm{ml}^{-1}$ by day 4 , irrespective of $\mathrm{DOC}$ concentration, and thereafter remained fairly constant.

The effect of $\mathrm{N}$ on measured availability was tested

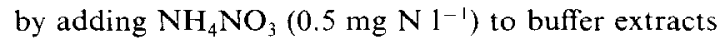
of the $0-20$ and $80-100 \mathrm{~cm}$ layers (winter). The effect of DOC concentration in the range present in the extracts $\left(0.5-8.0 \mathrm{mg} \mathrm{l}^{\cdots 1}\right)$ was tested by incubating a water extract of air-dry $0-20 \mathrm{~cm}$ soil diluted to 1,5 and $10 \mathrm{mg} \mathrm{DOC}^{-1}$. 
Table 2. Soil temperature and gravimetric water content at sampling

\begin{tabular}{|c|c|c|c|c|c|c|}
\hline \multirow[b]{2}{*}{ Depth $(\mathrm{cm})$} & \multicolumn{3}{|c|}{ Temperature $\left({ }^{\circ} \mathrm{C}\right)^{*}$} & \multicolumn{3}{|c|}{ Water content $(\%)$} \\
\hline & Winter & Spring & Summer & Winter & Spring & Summer \\
\hline $0-20$ & 4.1 & 12.8 & 19.7 & 20.6 & 14.8 & 10.0 \\
\hline $20-40$ & & & & 17.8 & 16.7 & 12.3 \\
\hline $40-60$ & 3.8 & 5.6 & 18.2 & 19.8 & 20.4 & 17.0 \\
\hline $60-80$ & & & & 27.7 & 23.4 & 20.6 \\
\hline $80-100$ & & & & 22.7 & 27.5 & 20.8 \\
\hline
\end{tabular}

${ }^{*} 10$ and $50 \mathrm{~cm}$ depth.

\section{Particle-size and density fractionation}

Field-moist samples (spring) from the $0-20$ and $80-100 \mathrm{~cm}$ layers of the profile were fractionated according to particle size and density. Samples were dispersed using an ultrasound probe set at $250 \mathrm{~W}$ for $10 \mathrm{~min}$. At this setting, probe output power, calibrated according to the method used by Gregorich et al. (1989) was $47 \mathrm{~W}$, which corresponded to an energy input of $225.6 \mathrm{~J} \mathrm{ml}^{-1}$ into the suspensions. Temperature was kept below $40^{\circ} \mathrm{C}$ by immersing the beakers in an ice bath during sonication. Dispersed samples were wet-sieved $(2 \mathrm{~mm})$ to remove gravel and coarse organic particles, and then at $50 \mu \mathrm{m}$. The $50-2000 \mu \mathrm{m}$ fraction was separated into low-density (light) and high-density (sand) fractions by flotation using $\mathrm{Na}$ polytungstate $\left[\mathrm{Na}_{6}\left(\mathrm{H}_{2} \mathrm{~W}_{12} \mathrm{O}_{40}\right) . \mathrm{H}_{2} \mathrm{O}\right.$, SOMETU, Berlin] solution with a density of $2.0 \mathrm{~g}$ $\mathrm{cm}^{-3}$. The $2-50 \mu \mathrm{m}$ fraction (silt) was recovered by repeated sedimentation. The $0.1-2 \mu \mathrm{m}$ fraction (clay) was recovered by centrifugation. The $<0.1 \mu \mathrm{m}$ supernatant (soluble fraction) was analysed for organic $\mathrm{C}$, dissolved salts (by electrical conductivity) and total solids content (by drying and weighing). A whole soil fraction of each depth was prepared using the same dispersal procedure described above and wet-sieving to $<2 \mathrm{~mm}$. All of the soil fractions thus collected, except the $<0.1 \mu \mathrm{m}$ fraction, were freeze-dried.

Availability of organic $C$ in particle-size and density fractions

Availability of organic $\mathrm{C}$ in particle-size and density fractions was measured as the increase in inorganic $C$ in the solution and gas phases of suspension incubations with soil inoculum. Thus, when referring to particle-size and density fractions, "available organic C" indicates that mineralized during the incubation. Incubation was carried out in suspension in order to eliminate differences in matric effects between the fractions. Aliquots of each fraction were placed in similar vials to those used for measuring availability of extracted organic C. Four replicates were used. Light fractions were ground with a mortar and pestle. Buffer $(50 \mathrm{ml})$ was added and the suspensions were shaken for $1 \mathrm{~h}$ at $20 \mathrm{C}$ in order for inorganic $\mathrm{C}$ (3.0 and $4.0 \mathrm{~g} \mathrm{~kg}^{-1}$, respectively, in the $0-20 \mathrm{~cm}$ silt and whole soil fractions; undetectable in all other fractions) to equilibrate with the liquid and gas phases in the vials. They were then inoculated with $1 \mathrm{ml}$ of soil suspension $(2 \mathrm{~g}$ fresh $0-20 \mathrm{~cm}$ soil in 11 . of $2.2 \mathrm{mM} \mathrm{Na}_{4} \mathrm{P}_{2} \mathrm{O}_{7}$, having $5.5 \times 10^{4} \mathrm{cfu} \mathrm{m}^{-1}$ and 16 $\mathrm{mg}$ total organic $\mathrm{Cl}^{-1}$ ). Vials were kept at $28^{\circ} \mathrm{C}$ in the dark on an orbital shaker. Immediately after inoculation (day 0), and after 24 days of incubation, inorganic $\mathrm{C}$ in the solution and gas phases was measured. Sterile (autoclaved) samples of the fractions containing detectable quantities of inorganic $\mathrm{C}$ were incubated in the same way, but without inoculation. Vials contained more than 5 times the amount of $\mathrm{O}_{2}$ needed to mineralize all of the organic $C$ present. Sand and gravel $(>2 \mathrm{~mm})$ fractions were not incubated because the organic $C$ content was too low to measure sufficiently accurately.

\section{RESULTS AND DISCUSSION}

\section{Microbial biomass and basal respiration}

Water content and temperature of the soil on the three sampling dates are shown in Table 2. Total organic $\mathrm{C}, \mathrm{C}-\mathrm{to}-\mathrm{N}$ ratio and biomass $\mathrm{C}$ diminished with depth (Table 1, Fig. 1). Near the surface, biomass was greatest in spring during the time of maximum pasture growth. The reductions at the other two sampling dates were presumably due to low temperature in winter and lower organic $\mathrm{C}$ inputs in winter and summer. Below $40 \mathrm{~cm}$, biomass $C$ was the same on the three sampling dates. Basal respiration profiles (Fig. 2) show that the biomass was more active at all depths in spring than in winter or summer,

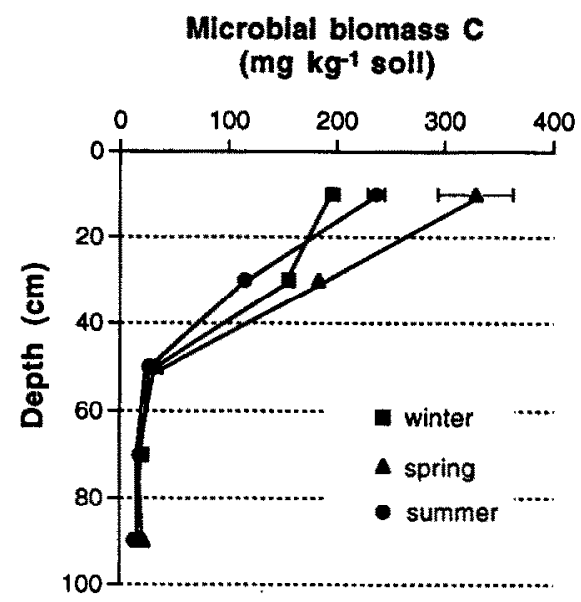

Fig. 1. Soil microbial biomass $C$. Data points in this and following figures represent results for layers sampled at $20 \mathrm{~cm}$ increments. Error bars show SD of the mean. 
Basal respiration rate (mg C $\mathrm{kg}^{-1}$ soll d-1)

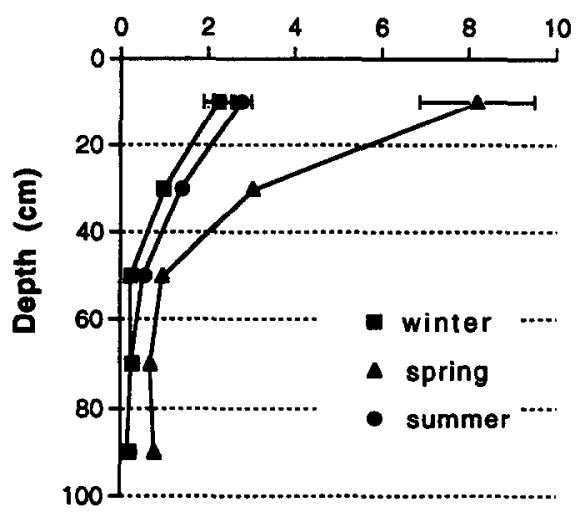

Fig. 2. Soil basal respiration rate.

especially near the surface. When expressed as a proportion of total organic $\mathrm{C}$, both biomass $\mathrm{C}$ and respired $C$ decreased with depth (Figs 3 and 4). Availability of soil organic $\mathrm{C}$ (ratio of respired $\mathrm{C}$ to total organic C) decreased 2- to 3-fold from the top to the bottom of the profile.

\section{Extracted organic $C$}

The amount of organic $\mathrm{C}$ extracted with water or phosphate buffer decreased with depth and was similar on the two sampling dates (Fig. 5). Phosphate buffer extracted approximately $7-12 \mathrm{mg} \mathrm{kg} \mathrm{kg}^{-1}$ soil more organic $\mathrm{C}$ than water at all depths. This organic $\mathrm{C}$ was most probably weakly adsorbed to inorganic colloid surfaces via polyvalent cation bridges, or complexed with polyvalent cations, as $\mathrm{Na}$ and $\mathrm{K}$ phosphate salts are known to release these forms of organic $\mathrm{C}$ (Hayes, 1985). The size of the extracted organic $C$ pool is larger when extraction procedures employing high temperature or high $\mathrm{pH}$ are used. However, high temperature

\section{Microblal blomass C -to- total organic C ratio $\left(\mathbf{g} \mathbf{k g}^{-1}\right)$}

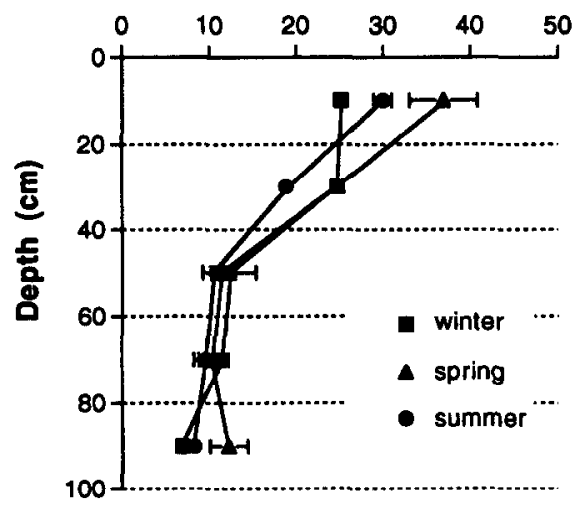

Fig. 3. Microbial biomass $C$ expressed as a proportion of total organic $\mathrm{C}$.

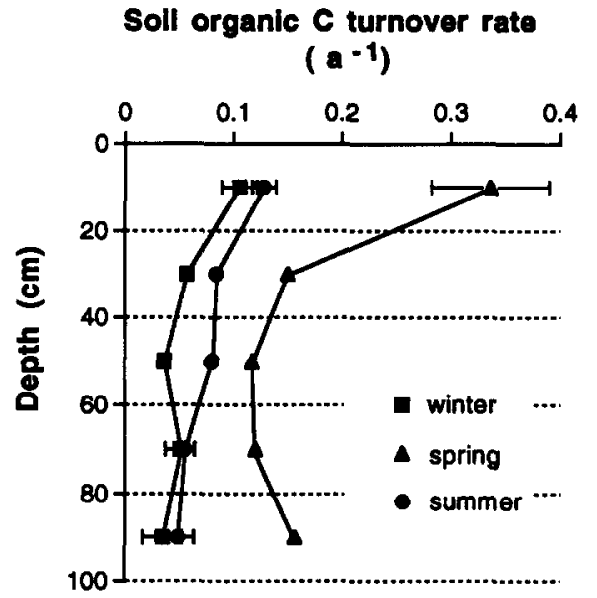

Fig. 4. Basal respiration rate expressed relative to total organic $\mathrm{C}$ (turnover of total organic $\mathrm{C}$ per annum).

and $\mathrm{pH}$ are known to cause hydrolysis of organic structures, lysis of cells and dissociation of organic materials from inorganic colloids. These changes mean that extracted organic $C$ is no longer the same as that available to organisms in undisturbed soil (Davidson et al., 1987; Oades, 1989). The procedures chosen for our work were very mild. Water extractability (the ratio of extracted organic $\mathrm{C}$ to total organic C) was constant with depth, while buffer extractability increased to a maximum at $40-80 \mathrm{~cm}$ due to an increase in the proportion or extractability of adsorbed organic $\mathrm{C}$.

\section{Availability of extracted organic $C$}

Although the measures of available organic $\mathrm{C}$ used in our work do not have an absolute value, they could be used to compare forms of organic $\mathrm{C}$ between depths. We assumed that organic $\mathrm{C}$ was the limiting nutrient in extracts. Addition of $N$ did not alter availability of organic $\mathrm{C}$ in the $80-100 \mathrm{~cm}$ soil extract, but increased availability from 23.8 to $29.9 \%$ in the

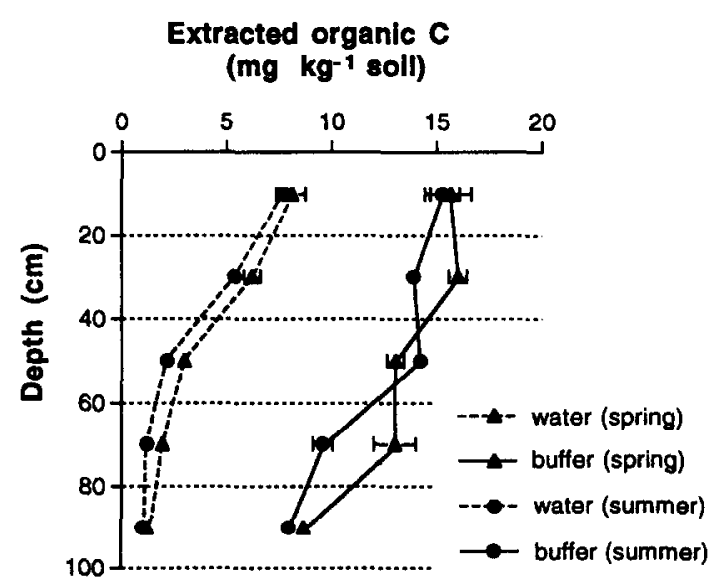

Fig. 5. Water- and buffer-extracted organic C. 
Avallable extracted organic C (mg kg-1 soil)

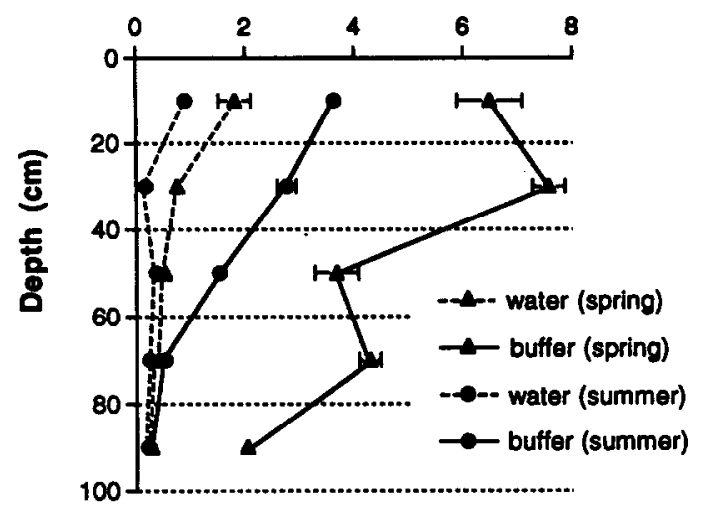

Fig. 6. Available water- and buffer-extracted organic C.

0-20 cm extract. As for the effect of initial DOC concentration, availability was significantly lower $(50.6 \%)$ at the low initial concentration than at the the medium and high concentrations (62.2 and $62.0 \%$, respectively). Therefore, the availability measured at low extract concentrations may have been an underestimate compared to that measured at medium and high concentrations. Incubation of known readily-available compounds using the same incubation conditions resulted in almost complete loss of DOC. Measured availability was $98.4,97.3$ and $98.2 \%$ for $\mathrm{Na}$ benzoate, $\mathrm{Na}$ acetate and glucose $\mathrm{C}$, respectively (each exposed at an initial DOC concentration of $5.6 \mathrm{mg} \mathrm{1}^{-1}$ ).

Availability of water-extracted organic $\mathrm{C}$ varied between 3 and $22 \%$, with a minimum at $20-40 \mathrm{~cm}$ depth. These values were similar to those obtained for soil leachates by Boissier and Fontvieille (1993) using a similar method. Availability of weakly-adsorbed organic $C$ (the difference between water and buffer-extracted organic $C$ ) decreased with depth (62 and $39 \%$ in spring and summer, respectively, at $0-20$ $\mathrm{cm}$ and 24 and $0 \%$, respectively, at $80-100 \mathrm{~cm}$ ). Weakly-adsorbed organic $\mathrm{C}$ thus appeared to be more labile than water-extracted organic C. Availability, and amount of available organic $\mathrm{C}$ in both water and especially buffer extracts was, higher in spring than in summer (Fig. 6). This was due presumably to pasture growth and hence exudation of soluble substrates by roots being more active in spring. Xu and Juma (1993) found that water-extracted organic $C$ released from roots was more readily available than that originating from soil organic $C$.

The relative contribution of extracted organic $\mathrm{C}$ to total available organic $\mathrm{C}$ at the different depths was compared by dividing the amount of available extracted organic $C$ by the soil basal respiration rate at each depth. The amount of available extracted $\mathrm{C}$ relative to soil respiration increased to a maximum at $40-80 \mathrm{~cm}$ depth, most of it being in the weakly-adsorbed pool (Fig. 7). If it is assumed that all respired
C flowed through the available extracted pools, the results would represent the "turnover times" of those pools. However, this assumption cannot be justified, as microorganisms can mineralize water-insoluble substrates.

\section{Particle-size and density fractionation}

Recovery of the soil after fractionation was $98.6 \%$ for the $0-20 \mathrm{~cm}$ sample and $101.1 \%$ for the $80-100 \mathrm{~cm}$ sample. Recovery of organic $C$ was 101.9 and $98.3 \%$ for the $0-20$ and $80-100 \mathrm{~cm}$ samples, respectively. The $>2 \mathrm{~mm}$ fraction contained $1.6 \%$ of the soil mass and $3.8 \%$ of the organic $\mathrm{C}$ at $0-20 \mathrm{~cm}$, and $0.5 \%$ of the soil and $0.5 \%$ of the organic $\mathrm{C}$ at $80-100 \mathrm{~cm}$. This fraction was excluded from further experimentation and calculations because it was so small and variable. At the surface most of the organic $\mathrm{C}$ was in the silt and clay fractions ( 38.6 and $49.6 \%$, respectively), while at depth $70.0 \%$ was in the clay fraction. The light fraction consisted of recognizable plant remains, such as straw, roots and seeds at the surface and roots only at depth. Sand fractions contained similar materials which had not been completely removed during the density separation. The "soluble" fraction consisted of salt, organic matter and fine clay $(23,4$ and $73 \%$, respectively, by mass in the $0-20 \mathrm{~cm}$ soil, and 30,3 and $68 \%$, respectively, in the $80-100 \mathrm{~cm}$ soil).

\section{Availability of organic $C$ in particle-size and density} fractions

The amount of inorganic $\mathrm{C}$ in the solution and gas phases did not increase during the incubation of sterile samples containing detectable quantities of inorganic C. Therefore, the increase in all of the non-sterile vials was attributed to mineralization of organic $C$. Available organic $\mathrm{C}$ was defined as that mineralized.

Availability of organic $\mathrm{C}$ in the whole soil fraction was less at $80-100 \mathrm{~cm}$ than at $0-20 \mathrm{~cm}$ (Table 3), but the difference between depths was much less than that

\section{Ratio of avall. extracted organic C to basal resp. rate (kg avall. extr. C (kg resp. C d $\left.\left.{ }^{1}\right)^{-1}\right)$}

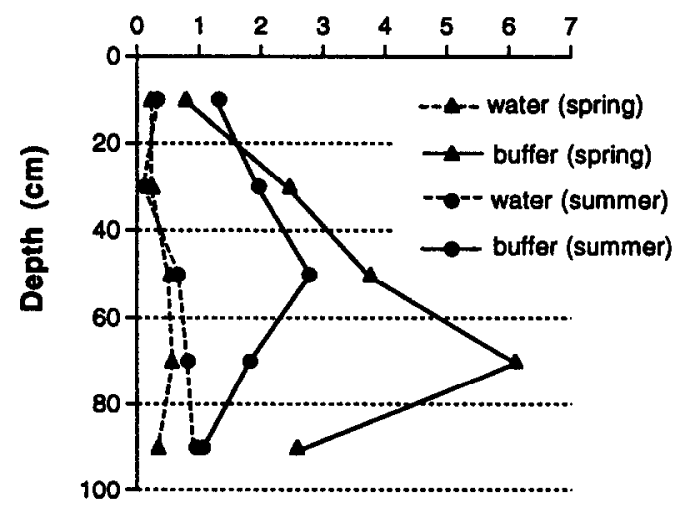

Fig. 7. Available water- and buffer-extracted organic $\mathrm{C}$ expressed relative to basal respiration rate. 
Table 3. Amount and availability of organic $\mathrm{C}$ in particle-size and density fractions

\begin{tabular}{|c|c|c|c|c|c|}
\hline Fraction & Soil $(\%)$ & $\begin{array}{c}\text { Organic C content } \\
(\%)\end{array}$ & $\begin{array}{c}\text { Amount of } \\
\text { organic } C \\
\left(\mathrm{mg} \mathrm{kg}^{-1} \text { soil }\right)\end{array}$ & $\begin{array}{c}\text { Availability of } \\
\text { organic } C^{*} \\
(\%)\end{array}$ & $\begin{array}{c}\text { Amount of available } \\
\text { organic } \mathrm{C} \\
\left(\mathrm{mg} \mathrm{kg}^{-1} \text { soil }\right)\end{array}$ \\
\hline \multicolumn{6}{|l|}{$0-20 \mathrm{~cm}$} \\
\hline Light & 0.4 & 19.19 & 768 & $4.04 \pm 0.08$ & 31 \\
\hline Sand & 22.7 & 0.07 & 159 & ND & \\
\hline Silt & 56.0 & 0.59 & 3304 & $2.64 \pm 0.05$ & 87 \\
\hline Clay & 18.5 & 2.29 & 4237 & $6.60 \pm 0.05$ & 279 \\
\hline Soluble & 1.0 & 2.48 & 248 & ND & \\
\hline Whole soil & 100.0 & 0.86 & 8550 & $5.73 \pm 0.08$ & 490 \\
\hline \multicolumn{6}{|l|}{$80-100 \mathrm{~cm}$} \\
\hline Light & 0.1 & 5.42 & 54 & $4.50 \pm 0.25$ & 2 \\
\hline Sand & 16.7 & 0.05 & 84 & ND & \\
\hline Silt & 36.8 & 0.08 & 294 & $2.60 \pm 0.05$ & 8 \\
\hline Clay & 47.1 & 0.26 & 1225 & $3.19 \pm 0.08$ & 39 \\
\hline Soluble & 0.4 & 1.58 & 63 & $\overline{N D}$ & \\
\hline Whole soil & 100.0 & 0.18 & 1750 & $4.33 \pm 0.14$ & 76 \\
\hline
\end{tabular}

*Proportion of organic $\mathrm{C}$ mineralized in 24 -day incubation. ND: not determined.

in undisturbed samples (Fig. 4). The comparison suggests that simple separation of substrate and organisms in undisturbed soil was more important as a stabilization mechanism at depth than at the surface. It also corresponds with the fact that extracted organic $\mathrm{C}$ contributed more to total available organic $\mathrm{C}$ at depth than at the surface, as soluble organic $C$ could move towards organisms by diffusion. Adu and Oades (1978) suggested that entrainment of substrate in pores too small for microorganisms was an important stabilization mechanism, and that it was more important for non-soluble substrates than soluble substrates. The contribution of weakly-adsorbed organic $C$ to respired $C$ decreased below $40-80 \mathrm{~cm}$ depth (Fig. 7). This may have been due to the large increase in clay content and hence the volume of pores too small for microorganisms (Adu and Oades, 1978).

At the surface, the availability of organic $\mathrm{C}$ in the fractions (Table 3 ) decreased in the order clay $>$ whole soil $>$ light $>$ silt, while at depth availability decreased in the order light $>$ whole soil $>$ clay $>$ silt. The sum of the amounts of readily-available organic $C$ in all fractions was less than that in the whole soil fraction $(81 \%$ at $0-20 \mathrm{~cm}$ and $64.5 \%$ at $80-100 \mathrm{~cm})$ for both depths. This difference was probably due to available organic C present in the "sand" and "soluble" fraction in whole soil samples.

Availability of organic $C$ was lowest in the silt fraction at both depths, corresponding with the results of similar incubation studies (Christensen, 1992). At the dispersion energies used, much of the "silt" fraction probably consisted of microaggregates (Gregorich et al., 1989) within which organic matter could be inaccessible to microorganisms. Only clay fraction organic $C$ was less available in the $80-100 \mathrm{~cm}$ layer than in the $0-20 \mathrm{~cm}$ layer. This difference in availability of clay fraction organic $\mathrm{C}$ between the two depths resulted in a corresponding difference in the availability of whole soil fraction organic $C$. While the proportion of organic $\mathrm{C}$ in the light fraction decreased with depth, its availability increased. The increase was probably due to the age of the plant residues in the light fractions. While at the surface they consisted largely of straw from previous crops, at depth they consisted of living roots only.

Although availability varied between the particlesize and density fractions, the variation was not large. Each fraction contained a small proportion of organic $\mathrm{C}$ which was fairly labile, while the major part was quite stable. Gregorich et al. (1989) reported similar results and estimated turnover times of organic $\mathrm{C}$ in labile and stable forms within particle-size fractions. Unavailability in the light fraction was presumably largely due to chemical recalcitrance. In the silt and clay fractions association with inorganic materials may also have played a part. Thus, the chemical recalcitrance of organic $\mathrm{C}$ in the clay fraction did not appear to be greater than that of light fraction organic C.

Acknowledgements-We are grateful to $\mathrm{Mr} \mathrm{B}$. Lagacherie for establishing the experimental site and to Mrs N. Rouard for technical assistance.

\section{REFERENCES}

Adu J. K. and Oades J. M. (1978) Physical factors influencing decomposition of organic materials in soil aggregates. Soil Biology \& Biochemistry 10, 109-115.

Anne P. (1945) Sur le dosage rapide du carbone organique des sols. Annales Agronomique 15, 161-172.

Beauchamp E., Trevors J. T. and Paul J. W. (1989) Carbon sources for bacterial denitrification. Adeances in Soil Science 10, 113-142.

Boissier J. M. and Fontvieille D. (1993) Biodegradable dissolved organic carbon in seepage waters from two forest soils. Soil Biology \& Biochemistry 25, 1257-1261.

Burford J. R. and Bremner J. M. (1975) Relatioriships between the denitrification capacities of soils and total, water-soluble and readily decomposable soil organic matter. Soil Biology \& Biochemistry 7, 389-394.

Chaussod R., Houot S.,Guiraud D. and Hetier J. M. (1988) Size and turnover of the microbial biomass in agricultural soils: laboratory and field measurements. In Nitrogen Efficiency in Agricultural Soils (D. S. Jenkinson and K. A. Smith, Eds), pp. 312 326. Elsevier, Amstcrdam.

Christensen B. T. (1992) Physical fractionation of soil and organic matter in primary particle size and density separates. Advances in Soil Science 20. 1-90. 
Davidson E. A., Galloway L. F. and Strand M. K. (1987) Assessing available carbon: comparison of techniques across selected forest soils. Communications in Soil Science and Plant Analysis 18, 45-64.

Dictor M. C., Soulas G., Takagi K., Anderson J. P. E., Lewis K. and Lewis F. (1992) Subsoil microbiology: microbial activity and potential for pesticide degradation in the unsaturated zone. In Proceedings of the International Symposium on Environmental Aspects of Pesticide Microbiology (J. P. E. Anderson, D. J. Arnold, F. Lewis and L. Torstensson, Eds), pp. 284-290. Swedish University of Agricultural Sciences, Uppsala.

Ghiorse W. C and Wilson J. T. (1988) Microbial ecology of the terrestrial subsurface. Advances in Applied Microbiology 33, 107-172.

Gregorich E. G. Kachanoski R. G. and Voroney R. P. (1989) Carbon mineralization in soil size fractions after various amounts of aggregate disruption. Journal of Soil Science 40, 649-659.

Hayes M. H. B. (1985) Extraction of humic substances from soil. In Humic Substances. In Soil, Sediment and Water; Geochemistry, Isolation and Characterisation (G. R. Aiken, D. M. McKnight, R. L. Wershaw and P. MacCarthy, Eds), pp. 329-362. Wiley, New York.

Nicolardot B., Cheneby D. and Allard M.R. (1992) Availability of carbon and nitrogen contained in different soil particle size fractions. In Humus, Its Structure and Role in Agriculture and Environment: Proceedings of the 10th Symposium Humus et Planta, Prague 1991 (J. Kubat, Ed.), pp. 107-116. Elsevier, Amsterdam.

Oades J. M. (1989) An introduction to organic matter in mineral soils. In Minerals in Soil Environments (J. B. Dixon and S. B. Weed, Eds), pp. 89-159. Soil Science Society of America, Madison, Wisc.

Servais P., Anzil A. and Ventresque C. (1989) Simple method for determination of biodegradable dissolved organic carbon in water. Applied and Environmental Microbiology 55, 2732-2734.

Shan-Min S., Brookes P. C. and Jenkinson D. S. (1987) Soil respiration and the measurement of microbial biomass by the fumigation technique in fresh and air-dried soil. Soil Biology \& Biochemistry 19, 153-158.

Wu J., Joergensen R. G., Pomerening B., Chaussod R. and Brookes P. C. (1990) Measurement of soil microbial biomass carbon by fumigation-extraction-an automated procedure. Soil Biology \& Biochemistry 22, 1167-1169.

Xu J. G. and Juma N. G. (1993) Above- and below-ground transformation of photosynthetically fixed carbon by two barley (Hordeum vulgare L.) cultivars in a typic cryoboroll. Soil Biology \& Biochemistry 25, 1263-1272.

Zsolnay A. and Steindl H. (1991) Geovariability and biodegradability of the water-extractable organic material in an agricultural soil. Soil Biology \& Biochemistry 23, 1077-1082. 